\title{
Factors Associated with Student Performance in Finance Electives: An Empirical Study at a US Private College
}

\author{
Dima Leshchinskii \\ Menlo College \\ Mostafa M. Maksy \\ Kutztown University of Pennsylvania
}

The paper studies factors affecting college student performance in upper-level finance electives. Of the motivation factors studied (intended grade, intention to take the CFA exam, or attend graduate school) only the first is significantly associated with student performance. None of the distraction factors (job hours, job type, and credit load) has any negative effect on student performance. Of the self-perceived ability factors (Writing, Math, Reading, and Listening) only Math has some association with student performance. The grade in Financial Management I, and GPA have significant associations with student performance. Finally, neither gender nor age has any significant association with performance.

Keywords: Motivation, Distraction, Student abilities, Student performance, Finance Electives

\section{INTRODUCTION}

Several prior research studies have explored various factors (e.g., general academic performance, aptitude, prior exposure to mathematics, prior exposure to accounting, age, gender, motivation, effort, and other intervening variables) that are associated with student performance in college-level courses. It is widely believed that motivation and effort significantly influence individual performance in college. However, as the review of prior research below indicates, very few studies have investigated their impact on undergraduate finance courses. This study investigates the associations between selected motivation, distraction, self-perceived ability, and prior ability factors and student performance in the undergraduate Finance Elective courses at a private college in the U.S.

As proxies for motivation, we use the grade the students intend to earn in the course, intention to take the Chartered Financial Analyst (CFA) exam and intention to attend graduate school. As proxies for distraction, we use the number of hours of work per week, the type of job (whether or not it is related to accounting, finance, or business in general) and the number of credit hours taken per semester. We measure students' self-perceived abilities using their own self-reported math, writing, reading, and listening abilities. Students' prior abilities are measured by the actual grade earned in the Financial Management I course Fin 320, which is a pre-requisite for the Finance Elective courses, and by Overall Grade Point Average (OGPA.) The dependent variable, the student performance, is measured in two different ways: the letter grade for the course, and the total overall points percent score (hereafter referred to as 'Points') for the course. 
One of the motivations of this study is predicated on the belief that identifying factors that motivate students to perform well and factors that distract them from performing well may help us emphasize the motivation factors and discourage the distraction factors. Another purpose of the study is to provide empirical support to the intuitive notion that motivation does indeed lead to better student performance. Also the study could help us determine whether students' self-assessment of their own writing, math, reading, and listening abilities affect their performance in the course.

The remaining parts of the paper present a review of prior research, analytical framework and hypotheses, study objectives, variables, research methodology, and results. The paper ends with conclusions, recommendations, study limitations, and some suggestions for further research.

\section{REVIEW OF PRIOR RESEARCH, ANALYTICAL FRAMEWORK AND HYPOTHESES}

Students' academic success is extremely important and colleges use various tools to improve academic performance. Several prior studies have examined the association between various factors and student performance in college-level courses.

We want to study how performance in elective finance courses (EFCs) is affected by these factors, which can be classified into the following groups: 1) students' motivation and effort, 2) distraction or intervening factors, 3) innate abilities, 4) prior exposure to and performance in related courses, and 5) demographic characteristics.

Factors in these groups are not independent and can correlate and interact with each other.

\section{Motivation and Effort}

Several theories link motivation factors to performance ${ }^{1}$ and there are numerous studies about the influence of motivation on student performance that report conflicting results. For example, Pascarella and Terenzini (1991), report that motivation and effort, among other factors, significantly influence students' performance in college. Wooten (1998) finds that motivation significantly affects effort which in turn significantly affects performance in an introductory accounting course. Maksy and Zheng (2008), and Gupta and Maksy (2014) use 'the grade the student intends to earn in the course' as a proxy for motivation and find it to be significantly associated with the student's performance in advanced accounting, auditing, and investment courses. Paulsen and Gentry (1995) report that students' academic performance in a large introductory Financial Management course was significantly related to several motivational variables such as intrinsic and extrinsic goal orientations and task value, and learning strategy variables, including time, study, and effort.

Johnson et al. (2002) utilize computerized quizzes and analyze the effect of objectively measured effort on student performance in Financial Management course. They show that, after controlling for aptitude, ability, and gender, effort, as measured by attempts and log time, remains significant in explaining the differences in performance. Rich (2006), uses students' homework preparedness and unpreparedness in class as a proxy for effort and non-effort. He finds significant positive association for the former and negative association for the latter with exam percent. On the other hand, Biktimirov and Klassen (2008) find weak association between hits to course management system and grade in finance course. Using self-reported data, Didia and Hasnat (1998) also present very weak counter-intuitive evidence for one of the two OLS models, but not for the ordered-probit models, that the more time spent studying per week the lower the grade in the Introductory finance course. However, they did not control for GPA. Also, using self-reported data, Nofsinger and Petry (1999) find no significant association between effort and performance in a Principles of Finance course.

In this study we posit that long-term goals serve as motivation factors and advance the following hypotheses:

$\boldsymbol{H}_{1}$ : There is a significant positive association between the grade the student intends to earn in EFCs and student performance in those courses. 
$\boldsymbol{H}_{2}$ : There is a significant positive association between the student's intention to take the Certified or Chartered Financial Analyst (CFA) exam and student performance in EFCs.

$\boldsymbol{H}_{3}:$ There is a significant positive association between the student's intention to attend graduate school and student performance in EFCs.

\section{Distraction Factors}

In recent years, there has been increased interest in studying the influence of intervening variables on student performance. One can argue that "students can put forth greater effort when there are fewer outside distractions from extracurricular, work and family activities" (Wooten, 1998). In line with this argument, Paulsen and Gentry (1995) find that academic performance in a large introductory financial management class is significantly related to control over learning, test anxiety, self-efficacy, elaboration, organization and metacognition.

Fewer outside distractions can also result in improved class attendance, thus leading to better academic performance. Tessema et al. (2014) report that if students work 10 hours or less per week they are more satisfied and have higher GPAs than students who work more than 10 hours per week. Paisey and Paisey (2004) and Guney (2009) have similar findings. Paisey and Paisey (2004) also report that the most frequently cited reason for not attending classes was students' participation in part-time employment.

Alternatively, one can argue that when time is a scarce resource, students are more focused on task in hand and use their time more efficiently. E.g., Rich (2006) reports significant negative association between exam performance and tardiness and absenteeism. Also, students might be self-aware of their own capabilities and students with higher GPAs take more courses per semester - Didia and Hasnat (1998) find strong positive association between number of credit hours enrolled in the semester and course grades. Maksy and Zheng (2008), Maksy (2012 and 2014), Gupta and Maksy (2014), and Maksy and Wagaman $(2012,2013$, and 2015) find no significant negative association between the number of hours of work per week and student performance in several accounting, auditing, and investment courses.

Other studies (Wooten, 1998; Chan et al., 1997; Van Ness et al., 2000) find no significant association between work, family, and extra-curricular conflicts and students' performance in classes. However, Van Ness et al. (2000) find that students who are enrolled in an internet class are more likely not to complete the course. This appears to be contrary to Paulsen and Gentry finding because the internet course is designed to give students more control over their learning in terms of very flexible deadline for assignments and one full year to complete the course.

We formulate the following hypotheses:

$\boldsymbol{H}_{4}:$ There is a significant negative association between the student's average number of hours of work per week and student performance in the EFCs.

$\boldsymbol{H}_{5}:$ There is a significant negative association between the student's job type (if it is not related to finance, accounting, or business in general) and student performance in the EFCs.

$\boldsymbol{H}_{6}:$ There is a significant negative association between the number of semester credit hours a student is taking and that student's performance in the EFCs.

\section{Self-perceived Abilities}

If students are accurate in estimating their own abilities, then self-perceived abilities will be positively correlated with academic performance, because students will correctly estimate their quantitative and other important skills that are important for achieving positive results. They will also increase selfefficacy - the level of confidence individuals have in their ability to accomplish tasks (Bandura, 1986), which will have a positive effect on the outcome as well. On the other hand, if self-perception is caused 
by overconfidence, it can result in no correlation, or even negative correlation. E.g., Chan et al. (1997) show that self-reported quantitative skills have insignificant impact on students' course score.

Hypothesis $\mathrm{H}_{1}$ already captures the relation between students' expectations and performance. The following hypotheses look at self-perceived abilities at a more granular level:

$\boldsymbol{H}_{7}$ : There is a significant positive association between the student's self-reported writing ability and student performance in the EFCs.

$\boldsymbol{H}_{8}:$ There is a significant positive association between the student's self-reported math ability and student performance in the EFCs.

$\boldsymbol{H}_{9}:$ There is a significant positive association between the student's self-reported reading ability and student performance in the EFCs.

$\boldsymbol{H}_{10}$ : There is a significant positive association between the student's self-reported listening ability and student performance in the EFCs.

\section{Prior Performance}

Finance and accounting are subject areas that require accumulation of prior knowledge and quantitative skills. Thus, several studies have investigated the impact of prior exposure to mathematics and accounting on performance in college finance and accounting courses. With regard to Financial Management courses, the evidence is mixed. Grover et al. (2010) report significant explanatory power for pre-test math, accounting and economics scores. Didia and Hasnat (1998) find mixed results with math grade being significant predictor of course grade for OLS model but not for the ordered-probit model. However, they find strong evidence, using both OLS and ordered-probit estimates, that grades in accounting and economics pre-requisite courses have predictive value for the Financial Management course. Sen, Joyce, Farrell and Toutant (1997) also find positive association between completion of prerequisites and performance in the Financial Management course.

Several researchers, using data from various U.S. colleges, find evidence supporting OGPA as a significant predictor of performance in accounting (Eckel and Johnson, 1983; Hicks and Richardson, 1984; Ingram and Peterson, 1987; Eskew and Faley, 1988; Doran et al., 1991; Maksy and Zheng, 2008; Maksy, 2012 and 2014; Gupta and Maksy, 2014; and Maksy and Wagaman, 2012, 2013, and 2015, and Alanzi, 2015) and required finance courses (Paulsen and Gentry, 1995; Chan, et al. 1997; Sen et al., 1997; Didia and Hasnat, 1998; Marks, 1998; Van Ness et al., 2000; Johnson et al., 2002; Biktimirov and Klassen, 2008).

Additionally, Tickell and Smyrnios (2005) find that the best predictor of academic performance in any given year is the performance in the same discipline in the previous year. Doran et al. (1991) report very surprising and counterintuitive result that performance in the introductory accounting course has a negative impact on performance in subsequent accounting courses. Maksy and Zheng (2008) and Maksy and Wagaman (2012, 2013, and 2015) find that OGPA and the grade in intermediate accounting II are strong predictors of student performance in advanced accounting, auditing, and senior seminar in accounting courses. Gupta and Maksy (2014) report that overall GPA and grades in Financial and Managerial Accounting courses are strong predictors of student performance in an Investment course.

By focusing on performance in EFCs, we test the following hypotheses:

$\boldsymbol{H}_{11}$ : There is a significant positive association between the grade the student earned in the Financial Management I course and student performance in the EFCs.

$\boldsymbol{H}_{12}$ : There is a significant positive association between the student's OGPA and student performance in the EFCs. 


\section{Demographic Characteristics and Other Factors}

Age and gender are two demographic variables that receive less attention than those factors discussed above and will be used as controls. Prior studies' results are inconclusive. Chan et al. (1997), Didia and Hasnat (1998), Henebry and Diamond (1998), Johnson et al. (2002) and Van Ness et al. (2000) find no significant association between grade in an introductory finance course and gender or age of students. Sen et al. (1997), on the other hand, show that female students performed worse than male students in principles of finance courses at two different mid-western universities. In the field of accounting, Bartlett et al. (1993) and Kohl and Kohl (1999) suggest that younger students have better performance, particularly at the senior university level. However, Jenkins (1998) and Lane and Porch (2002) conclude that age is not a significant determinant of performance in auditing and management accounting courses. Also, Schrouder and Rhodd (2013) report that older and more experienced students perform better than younger and less experienced students in a Public Administration course. The studies related to gender also produce conflicting results. Some studies indicate that male students perform better than female ones, but the results are either insignificant (for example, Lipe, 1989) or only hold true for introductory courses (Doran el al., 1991). To the contrary, Mutchler et al. (1987) find that female students score significantly higher than male students. In contrast, other studies find no significant differences in performance between male and female accounting students. For example, Tyson (1989) and Buckless et al. (1991) demonstrate that gender effect disappears after controlling for general academic ability. Similarly, Gammie et al. (2003) find very little indication of performance differential between males and females throughout the degree program.

In light of the above review of prior research related to age and gender, we formulate the following hypotheses:

$\boldsymbol{H}_{13}$ : There is no significant positive association between the student gender and student performance in the EFCs.

$\boldsymbol{H}_{14}$ : There is no significant positive association between the student age and student performance in the EFCS

There is very limited, almost non-existent, literature on student performance in upper level finance classes. Dolvin and Pyles (2011) find that trading simulation performance in an Investments class has no significant impact on knowledge level and interest in the discipline or the investment profession. Huffman (2011) finds that the real estate major status is associated with higher grade performance in an advanced real-estate course.

While prior research has been largely inconclusive or replete with conflicting results, it is not our purpose in this study to resolve all these conflicts. Our hope, in this study, is to provide more insight on those areas in which there was some general agreement. Since motivation and effort have generally been positively associated with student performance, we try, in this study, to test whether some new selected motivation factors affect student performance in the EFCs. We also look at several factors which are commonly viewed as possibly distracting students from performing well and test whether they indeed are negatively affecting student performance. Moreover, we investigate the impact of three specific measures of prior abilities on student performance, and also use them as control variables while testing for the association between motivation and distraction factors and student performance in the EFCs.

\section{STUDY OBJECTIVES}

Summarizing our prior discussion, this study has the following objectives. The first objective is to examine the relationship between three selected motivation factors (the grade the student intends to earn in the course, the student's intention to take the chartered financial analyst (CFA) exam, and the student's intention to attend graduate school), and the student's performance in two EFCs: Financial Management II and Entrepreneurial Finance at a small private college. We hypothesize that there are positive and 
significant relationships between those motivation factors and student performance. That is, students who intend to earn higher grades; take the CFA exam, or attend graduate school are motivated to perform well in these EFCs to achieve their intentions.

The second objective is to study the association between three selected distraction factors (the student's number of working hours per week during the semester, the student's job type, i.e., whether it is related to finance, accounting, or business in general, and the student's number of credit hours taken in the semester), and the student's performance in the EFCs. Intuitively, the higher the number of work hours per week, the less time the student will have to study for the EFCs resulting in lower course grade and points. Furthermore, if the student's job is not related to finance, accounting, or business in general, the student's grade in the EFCs will be lower than if the student's job is related to one of these areas. Finally, we hypothesize that the performance of a student taking higher number of credit hours will be affected negatively because the student may not be able to devote sufficient number of hours of study for the EFCs. In light of this discussion, we hypothesize that if the student's number of work hours per week is higher, and/or the student's job is not related to finance, accounting, or business in general, and/or the number of credit hours taken in the semester is higher, there will be a significant negative association between these distraction factors and the student's performance in the EFCs. Distraction factors may potentially offset each other thereby reducing the impact of any single factor. For example, a student who works more hours per week may take fewer credit hours, and vice versa, so there may be no net impact on performance. For this reason, we test the effect of each distraction factor on student performance while controlling for the other two factors. We also investigate the associations among the distraction factors themselves.

The third objective is to study the relationship between students' performance in the EFCs and their current self-perceived abilities in math, writing, reading, and listening. A positive association between self-reported abilities and performance may indicate that students make reasonably accurate assessment of their abilities. A lack of positive and significant association between certain abilities and performance could be interpreted as those abilities being irrelevant to the performance in the course or could indicate an inaccurate self-assessment of abilities. Before the students filled out the questionnaires, they were encouraged to be as honest as possible in their answers so future students could potentially benefit from the results of the research. Assuming controlled response bias, we hypothesize positive and significant associations between students' self-perceived abilities and their performance in the EFCs.

The fourth objective is to study the relationship between students' prior abilities such as their OGPA as well as their grades in a prerequisite course - Financial Management I - and student performance in the EFCs. Since the topics covered in Financial Management I are directly related to the topics covered in the EFCs, we hypothesize that there are positive and significant associations between these prior actual abilities and student performance in the EFCs.

The fifth objective is to study the association between students' gender and age and their performance in the EFCs. Based on the results obtained by most prior research, we hypothesize that students' gender and age will have no effect on their performance in the EFCs.

\section{STUDY VARIABLES}

In addition to the 14 independent variables described above, we use two dependent variables. Initially, we used only the letter grade in the course (A, A-, B+, etc.) as a dependent variable to measure the student performance. However, we realized that the letter grade treats a student earning the lowest end of the grade range as having the same exact performance as that of a student earning the highest end of the grade range. For example, student with a total percentage points of 82 and another with a total percentage points of 86 would be considered having equal performance since both students receive a letter grade of B for the course, even though the first student is one percentage point away from a Bgrade and the other student is one percentage point away from a $\mathrm{B}+$ grade. As a result, in addition to letter grade, we also decided to use overall points percentage earned by a student (before any curving) in the course as a dependent variable. 


\section{RESEARCH METHODOLOGY}

\section{Survey Instrument}

We modified a list of survey questions, from Ingram et al. (2002), to include study variables, demographics, and other information. For ethical, confidentiality, and potential risk issues pertaining to participants, the authors had to submit an application (together with a copy of the survey instrument) to the College's Institutional Review Board (IRB) for approval.

\section{Study Sample}

In fall 2018, we collected the data on the survey instrument from 48 of 52 students enrolled in two undergraduate EFCs offered at a US small private college. The college enrolls approximately 745 students. The instructor teaching the two EFCs provided data representing the two dependent variables (the 'letter grade,' and 'overall points' before any curving). Performance data was matched with survey responses using only student ID numbers for confidentiality purposes.

The author who was not the instructor of the two courses entered the data from the questionnaires on an Excel spreadsheet using only the students ID's for confidentiality reasons.

Table 1 (all tables are in Appendix) presents descriptive statistics (minimum, maximum, mean, and standard deviation) of all variables used in the study. It is interesting to note that the mean of Intended Grade of 3.50 is higher than the mean of the Letter Grade of 3.02 earned in the courses. It is also higher than the mean of each of the prior ability factors (the grade in Financial Management I, and overall GPA) -3.07 and 3.28 respectively. It is even higher than the mean of each of the self-perceived ability factors (Writing, Math, Reading, and Listening) that have means of 2.98, 3.26, 3.09, and 3.15 respectively. This indicates that the students were overly optimistic about the grades they intended to earn in the EFCs, which suggests students' overconfidence.

\section{Data Analysis}

To test the formulated hypotheses we use one-way analysis of variance (ANOVA), Pearson and Spearman's correlation coefficients and ordinary least square linear (OLS) regressions.

\section{STUDY RESULTS}

The analysis of the statistical results of the association between student performance and the five categories of independent factors; Motivation, Distraction, Self-perceived Abilities, Prior Abilities, and Other factors are presented in the following five sections.

\section{Motivation Factors Associated with Student Performance}

The results of association between student performance and the three motivation variables as discussed in $\mathrm{H}_{1}$ to $\mathrm{H}_{3}$ are presented in Tables 2 to 6 . The results show that the grade students intend to earn in the EFCs (Intended Grade, or IG) is significantly associated with student performance (however defined) based on One-Way ANOVA, in Table 2, (at the .01 level of significance). The same is true based on Pearson Correlation, in Table 3, except that the significance level is only at .10 when performance is defined as Grade and at .05 when performance is defined as Points. On the other hand, Spearman correlations, in Table 3, do not show any significant association between IG and student performance when it is defined as grade but show significant association only at the .10 level when performance is defined as Points. Table 4 presents the results after controlling for prior ability, as measured by the grade earned in the pre-requisite Financial Management I course as well as OGPA. The results indicate that the associations of between IG and student performance exhibited under Pearson and Spearman correlations totally disappeared. Furthermore, the regression test results provided in Table 5 do not show any significant association between IG and student performance. However, when we regress only motivation variables on student performance as shown in Table 6, we find a significant association between IG and student performance (at the .10 level when it is defined as grade and at the .05 level when it is defined as 
Points). The two other motivation variables discussed in $\mathrm{H}_{2}$ and $\mathrm{H}_{3}$ have no significant association (under any statistical test) with student performance (however defined).

\section{Distraction Factors Associated with Student Performance}

Tables 2, 3, 4 and 7 show that none of the three distraction factors (Job Hours, Job Type, and Credit Load) has any significant association with student performance under any tests. Therefore, we conclude that none of the three distraction factors is negatively related to student performance. Even when we regress only distraction variables on student performance, as shown in Table 7, we find no significant association between any of the three distraction factors and student performance. The results are consistent with Chan et al. (1997), Wooten (1998), and Gupta and Maksy (2014), who find that work hours do not affect student performance, and with Maksy and Rezvanian (2017) who find that Work Hours, Job Type, and Course Load do not affect student performance in an Introductory Finance course at a commuter school. Panels A and B of Table 11, present partial correlation coefficients of a selected distraction factor (while controlling the other two factors) with and without prior actual ability factors. The results show that none of the coefficients is statistically significant indicating that the distraction factors have no effect on the student performance. These results are also consistent with the results reported by Gupta and Maksy (2014).

\section{Self-perceived Abilities Factors Associated with Student Performance}

The ANOVA test in Table 2 shows that, of the four self-perceived ability factors (Writing, Math, Reading, and Listening), only Math has a significant association with student performance, but only when performance is defined as Points and only at the .10 level of significance. None of the other statistical tests in Tables 3, 4, and 5 shows any significant association between any of the self-perceived abilities and both measures of student performance. Even when we performed regression analyses using only selfperceived ability factors as independent variables to explain student performance, the results presented in Table 8 still show no significant association between any of the four self-perceived abilities and student performance, however defined. So, we can generally conclude that either these abilities are irrelevant to the performance in the EFCs or, most probably, the student over estimated their prior abilities.

\section{Prior Actual Ability Factors Associated with Student Performance}

The ANOVA, and Pearson and Spearman correlation tests, shown in Tables 2 and 3, indicate positive and statistically significant associations (at the .01 significance level) between student performance (however defined) in the EFCs and their prior performance in Financial Management I as well as their overall academic performance using OGPA. The regression test presented in Table 5 shows significant association between student performance and their OGPA (at the 10 level when performance is defined as grade and at .01 level when performance is defined as points), but it does not show any significant association between their grades in Financial Management I and student performance, however defined. As Table 9 indicates, the results stay the same when we regress only the two prior ability factors against student performance except that the significance level strengthens to .05 when performance is defined as Grade.

\section{Other Factors Associated with Student Performance}

None of the tests used in the study shows that gender has any significant effect on performance in the EFCs. However, the ANOVA test, presented in Table 2, shows a significant association (but only at the weakest level of .10) between age and student performance (only when it is defined as points). Because of the nature of the ANOVA test, we cannot tell from this significant association which age (younger or older) performs significantly better than the other. To find out, we ran cross tabulation of age and student performance, defined as Grade (we did not run cross tabulation between age and points because there are 47 classifications of points which is too large) and the results are shown in Table 12. From that table we can initially say that students whose age ranges from 18 to 22 years perform significantly better that student whose age ranges from 23 to 27 years. However, most probably, the significant difference in this 
case is driven by the fact that the majority of the students, 39 (or $81.25 \%$ ) of the 48 students fall in the first age category of 18 to 22. If the two age groups have equal number of students this significant difference will most likely disappear. Furthermore, the Pearson and Spearman correlation tests in Table 3, the partial correlation test in Table 4 as well as the regression test in Table 5 did not show any significant association between age and student performance, however defined, except for weak (at 0.1 level) negative Pearson correlation of points and age in Table 4. When we regressed gender and age only on student performance in Table 10, we found significantly negative association (at the .05 level) between age and student performance meaning the older the age the lower points. However, as discussed above, this is most likely caused by the significant difference in the size of the two age groups: 39 vs. 9 students. In general, we can state that the overall results support hypotheses 13 and 14.

\section{CONCLUSIONS AND RECOMMENDATIONS}

Several important conclusions can be drawn from the results of this study. The first conclusion is that motivated students, when motivation is proxied by intended grade, perform better than non-motivated students. Interestingly, as Table 1 shows, the average Intended Grade of 3.50/4.00 reported by the students at the beginning of the semester was significantly higher than the actual average grade of 3.02/4.00 earned by students. This simply implies that at the beginning of the semester, students were motivated to do well in the course. Since we could not find any association between intention to take the CFA exam or attend graduate school and student performance, it is unlikely that encouraging students to plan to take the CFA exam or pursue graduate studies would result in motivating students to increase the time and effort to improve performance in the EFCs.

The second conclusion drawn from the statistical results of this study is that the activities that faculty may consider as distractions (proxied by the number of hours of work per week, working in non-finance, non-accounting, or non-business-related jobs, and number of credits taken in the semester) do not seem to keep students from earning higher grades in the EFCs. These results contradict the common believe that studying full-time and working part-time may harm student performance. Therefore, when advising students with poor performance, the advisors should consider causes other than the employment status, type of job, or credit load.

The third conclusion of the study is that students' estimate of their own current perceived abilities (e.g., writing, math, reading and listening) have no significant association with students' performance in the EFCs. Although this study does not confirm any positive association between student performance in EFCs and their current perceived abilities in these areas (which is most likely resulting from students with low performance over-estimating their abilities), we believe that having soft skills are important factors for overall career development and the future success of business students. This has been documented in many of the other previous studies. Therefore, we suggest that faculty and schools of business academic advisors continue to emphasize the importance of students writing, math, reading and listening skills.

The fourth conclusion of the study is that students' prior actual ability, measured by higher grade received on the prerequisite course (Financial Management I), and their OGPA, are strong predictors of performance in the EFCs. In light of this conclusion, we recommend that college of business faculty and advisors should highlight the importance of pre-requisite courses, such as Math, and Financial Management to their advisees, and enforce the pre-requisite requirements for the EFCs.

The fifth conclusion of the study is that gender and age do not have any effect on student performance in the EFCs. Therefore, we recommend that advisors, when advising relatively older students, tell those students that no matter how old they are they can still perform well in the EFCs.

\section{STUDY LIMITATIONS AND SUGGESTIONS FOR FURTHER RESEARCH}

This study is subject to some limitations. One of the limitations is that the school under this study is a small private residential college with a few transfers and part time students. Therefore, the conclusions drawn from this study may not be applicable to large commuter schools with higher percentage of part 
time, transfers, and returning students. A suggestion for further research is to replicate the study at a large private or public school. One other suggestion is to replicate the study at a large private or public commuter school. Another limitation of the study is that the study sample size may not be large enough relative to the number of independent variables analyzed and, hence, the results should be considered cautiously. A suggestion for further research is to replicate the study using a larger sample, perhaps collecting data over two or three semesters.

\section{ENDNOTE}

1. Examples include, but are not limited to, Martin Ford's motivation systems theory, which posits that motivation is needed for a person to achieve set goals ( (Ford, 1992) and Expectancy-value theory (Keller, 1983).

\section{REFERENCES}

Alanzi, K. A. (2015). Determinants of Students' Performance in Cost Accounting-Further Evidence from Kuwait. World Journal of Management, 6(1), 136-152.

Bandura, A. (1986). Social foundations of thought and action: A social cognitive theory. Englewood Cliffs, NJ: Prentice-Hall, Inc.

Bartlett, S. M., Peel, J., \& Pendlebury, M, (1993). From Fresher to Finalist: A Three-year Study of Student Performance on an Accounting Degree Program. Accounting Education: An International Journal, 2, 111-122.

Biktimirov, E.N., \& Klassen, K.J. (2008). Association between Use of Online Support Materials and Student Performance in an Introductory Finance Course. Journal of Education for Business, 8, 153-158.

Buckless, F. A., Lipe, M. G., \& Ravenscroft, S.P., (1991). Do Gender Effects on Accounting Course Performance Persist After Controlling for General Academic Aptitude? Issues in Accounting Education, 6, 248-261.

Chan, K. C., Shum, C., \& Wright, D. J. (1997, Fall/Winter). Class Attendance and Student Performance in Principles of Finance. Financial Practice and Education, 7(2), 58-65.

Didia, D., \& Hasnat, B. (1998). The Determinants of Performance in the University Introductory Finance Course. Financial Practice and Education, 1(1), 102-107.

Dolvin, S. D., \& Pyles, M. K. (2011). The Influence of Simulation Performance on Student Interest. Journal of Economics and Economic Education Research, 12(3), 35-48.

Doran, B., Bouillon, M. L., \& Smith, C.G. (1991). Determinants of Student Performance in Accounting Principles I and II. Issues in Accounting Education, 6(1), 74-84.

Eckel, N., \& Johnson, W.A. (1983). A Model for Screening and Classifying Potential. Accounting Education, 2, 1-15.

Eskew, R. K., \& Faley, R. H. (1988). Some Determinants of Student Performance in the First Collegelevel Financial Accounting Course. The Accounting Review, 63(1), 137-147.

Ford, M. (1992). Motivating humans: Goals, emotions, and personal agency beliefs. NewBury Park, CA: Sage Publications.

Gammie, E., Paver, B., Gammie, B., \& Duncan, F. (2003). Gender Differences in Accounting Education: An Undergraduate Exploration. Accounting Education, 12, 177-197.

Grover, G., Heck, J., \& Heck, N. (2010). Pretest in an Introductory Finance Course: Value Added? Journal of Education for Business, 85, 64-67.

Guney, Y. (2009). Exogenous and Endogenous Factors Influencing Students' Performance in Undergraduate Accounting Modules. Accounting Education, 18, 51-73.

Gupta, K., \& Maksy, M. (2014). Factors Associated with Student Performance in an Investments Course: An Empirical Study. Journal of Finance and Accountancy, 16, 86-112. 
Henebry, K., \& Diamond, J. (1998). The Impact of Student and Professor Gender on Grade Performance in the Managerial Finance Course. Financial Practice and Education, 8(1), 94-101.

Hicks, D. W., \& Richardson, F. M. (1984). Predicting Early Success in Intermediate Accounting: The Influence of Entry Examination and GPA. Issues in Accounting Education, 2(1), 61-67.

Huffman, F. E. (2011). Student Performance in an Undergraduate Advanced Real Estate Course: Real Estate Majors vs. Finance Majors. Journal of Real Estate Practice and Education, 14(2), 111123.

Ingram, R. W., \& Peterson, R. J. (1987). An Evaluation of AICPA Tests for Predicting the Performance of Accounting Majors. The Accounting Review, Januray, 215-223.

Ingram, R. W., Albright, T. L., \& Baldwin, A. B. (2002). Financial Accounting - a Bridge to Decision Making. Cincinnati, OH: Thomson South-Western.

Jenkins, E. K. (1998). The Significant Role of Critical Thinking in Predicting Auditing Students' Performance. Journal of Education for Business, 5, 274-280.

Johnson, D. L., Joyce, P., \& Sen, S. (2002). An Analysis of Student Effort and Performance in the Finance Principles Course. Journal of Applied Finance, 12(2), 67-72.

Kohl, M. Y., \& Kohl, H. C. (1999). The Determinants of Performance in an Accountancy Degree Course. Accounting Education: An International Journal, 1, 13-29.

Keller, J. (1983). Motivational Design of Instruction. In C. Reiguluth, Instructional-Design Theories and Models: An Overview of their Current Status (pp. 383-433). Hillsdale, NJ: Lawrence Erlbaum Associates.

Lane, A., \& Porch, M. (2002). The Impact of Background Factors on the Performance of No specialist Undergraduate Students on Accounting Modules - A Longitudinal Study: A Research Note. Accounting Education, 1, 109-118.

Lipe, M. G. (1989). Further Evidence on the Performance of Female Versus Male Accounting Students. Issues in Accounting Education, 4(1), 144-152.

Maksy, M., \& Zheng, L. (2008). Factors Associated with Student Performance in Advanced Accounting and Auditing: An Empirical Study in a Public University. Accounting Research Journal, 21, 16-32.

Maksy, M. (2012). Major Factors Associated with the Performance of Students Taking Undergraduate Accounting Courses at the Upper Level, International Journal of Business, Accounting, and Finance, 6(2), 1-19.

Maksy, M., \& Wagaman, D. (2012). Factors Associated with Student Performance in Auditing: A Comparative Study in Commuter and Residential Schools. Journal of Accounting and Finance, 12(2), 120-141.

Maksy, M., \& Wagaman, D. (2013). Factors Associated with Student Performance in the Undergraduate Senior Seminar in Accounting: A Comparative Study in Commuter and Residential Schools. Journal of Applied Business and Economics, 14(4), 101-119.

Maksy, M. (2014). Factors Associated with Student Performance in Intermediate Accounting: A comparative Study at Commuter and Residential Schools. Journal of Applied Business and Economics, 16(5), 86-104.

Maksy, M., \& Wagaman, D. (2015). Factors Associated with Student Performance in Advanced Accounting: A comparative Study at Commuter and Residential Schools. Journal of Accounting and Finance, 15(1), 72-94.

Marks, B. R. (1998). An Examination of the Effectiveness of a Computerized Learning Aid in the Introductory Graduate Finance Course, Financial Practice and Education, 8(1), 127-132.

Mutchler, J. E., Turner, T. H. \& Williams, D.D. (1987). The Performance of Female versus Male Accounting Students. Issues in Accounting Education, 1, 103-111.

Nofsinger, J., \& Petri, G. (1999). Student Study Behavior and Performance in Principles of Finance. Journal of Financial Education, (Spring), 33-41. 
Paisey, C., \& Paisey, N. (2004). Student Attendance in an Accounting Module - Reasons for Nonattendance and the Effect on Academic Performance in a Scottish University. Accounting Education, 13, 39-53.

Pascarella, E., \& Terenzini, P. (1991). How College Affects Students: Findings and Insights from Twenty Years of Research. San Francisco, CA: Jossey-Bass Publisher.

Paulsen, M. B., \& Gentry, J. A. (1995). Motivation, Learning Strategies, and Academic Performance: A Study of the College Finance Classroom. Financial Practice and Education, 5(1), 78-89.

Rich, S. P. (2006). Student Performance: Does Effort Matter? Journal of Applied Finance, 16(2), 120 133.

Schrouder, S.M., \& Rhodd, R. G. (2013). Non-Intellectual Variables as Factors in Determining Academic Success - Are Older Students Likely to be More Successful? International Journal of Education and Research, 1(6), 1-12.

Sen, S., Joyce, P., Farrell, K., \& Toutant, J. (1997). Performance in Principles of Finance Courses by Students with Different Specializations. Financial Practice and Education, 7(2), 66-73.

Tessema, M.T., Ready, K. J., \& Stani, M. A. (2014). Does Part-Time Job Affects College Students' Satisfaction and Academic Performance (GPA)?: The Case of a Mid-Sized Public University, International Journal of Business Administration, 5(2), 50-59.

Tickell, G., \& Smyrnios, K (2005). Predictors of Tertiary Accounting Students' Academic Performance: A Comparison of Year 12-to-University Students with TAFE-to-University Students. Journal of Higher Education Policy and Management, 27, 239 - 259.

Tyson, T. (1989). Grade Performance in Introductory Accounting Courses: Why Female Students Outperform Males. Issues in Accounting Education, 4(1), 153-160.

Van Ness, B. F., Van Ness, R. A., \& Adkins, R. L. (2000). Student Performance in Principles of Finance: Difference Between Traditional and Internet Settings. Financial Practice and Education, 10(2), $160-166$.

Wooten, T. (1998). Factors Influencing Student Learning in Introductory Accounting Classes: A Comparison of Traditional and Nontraditional Students. Issues in Accounting Education, 13(2), 357-373. 


\section{APPENDICES}

TABLE 1

DESCRIPTIVE STATISTICS FOR THE STUDY NON-BINARY VARIABLES

\begin{tabular}{|c|c|c|c|c|c|}
\hline & $\mathrm{N}$ & Minimum & Maximum & Mean & $\begin{array}{l}\text { Std. } \\
\text { Deviation }\end{array}$ \\
\hline Letter Grade $^{1}$ & 48 & 0.0 & 4.0 & 3.02 & .977 \\
\hline Overall Points (in \%) & 48 & 54.01 & 101.60 & 84.12 & 9.924 \\
\hline Intended Grade ${ }^{2}$ & 48 & 2 & 4 & 3.50 & .546 \\
\hline Intended CFA ${ }^{3}$ & 47 & 1 & 3 & 2.17 & .702 \\
\hline Intended Grad School ${ }^{3}$ & 47 & 1 & 3 & 2.19 & .711 \\
\hline Job Hours & 48 & 0 & 60 & 13.17 & 11.661 \\
\hline Job Type ${ }^{4}$ & 48 & 0 & 4 & 2.17 & 1.155 \\
\hline Credit Load & 48 & 9 & 24 & 15.88 & 2.623 \\
\hline Writing Ability ${ }^{5}$ & 47 & 2 & 4 & 2.98 & .642 \\
\hline Math Ability ${ }^{5}$ & 47 & 2 & 4 & 3.26 & .765 \\
\hline Reading Ability ${ }^{5}$ & 47 & 2 & 4 & 3.09 & .747 \\
\hline Listening Ability $^{5}$ & 47 & 2 & 4 & 3.15 & .807 \\
\hline FIN 320 Grade $^{1}$ & 48 & .7 & 4.00 & 3.07 & .812 \\
\hline OGPA (out of 4.0 ) & 48 & 2.01 & 4.00 & 3.28 & .479 \\
\hline Gender $^{6}$ & 48 & 1 & 2 & 1.38 & .489 \\
\hline $\mathrm{Age}^{7}$ & 48 & 1 & 2 & 1.19 & .394 \\
\hline \multicolumn{6}{|c|}{$\begin{array}{l}{ }^{1} \mathrm{~A}=4.00 ; \mathrm{A}-=3.7 ; \mathrm{B}+=3.3 ; \mathrm{B}=3.00 ; \mathrm{B}-=2.7 ; \mathrm{C}+=2.3 ; \mathrm{C}=2.00 ; \mathrm{C}-=1.7 ; \mathrm{D}+=1.3 ; \mathrm{D}=1.00 ; \\
\mathrm{D}-=.7 ; \mathrm{F}=0.00 . \\
{ }^{2} \mathrm{~A}=4.00 ; \mathrm{B}=3.00 ; \mathrm{C} \text { or below }=2.00 . \\
{ }^{3} \text { No }=1 ; \text { Maybe }=2 ; \text { Yes }=3 \\
{ }^{2} \text { Do Not Work }=1, \text { Other }=2 ; \text { Business or Accounting Related (but not finance) }=3 ; \\
\text { Finance related }=4 ; \\
{ }^{5} \text { Very Good }=4 ; \text { Good }=3 ; \text { Average }=2 ; \text { Poor }=1 \\
{ }^{6} \text { Male }=1 ; \text { Female }=2 \\
{ }^{7} 18-22=1 ; 23-27=2 ; \text { Over } 27=3\end{array}$} \\
\hline
\end{tabular}


TABLE 2

ONE-WAY ANALYSIS OF VARIANCE

(All numbers are for Between Groups Only)

\begin{tabular}{|l|c|c|c|c|c|}
\hline \multicolumn{2}{|l|}{} & \multicolumn{4}{c|}{ Dependent Variables } \\
\hline $\begin{array}{l}\text { Independent } \\
\text { Variables }\end{array}$ & DF & F Value & Sig. & F Value & Sig. \\
\hline IG & $2 / 47$ & 6.138 & $.004 * * *$ & 6.247 & $.004 * * *$ \\
\hline ICFA & $2 / 46$ & .297 & .744 & .254 & .777 \\
\hline IGS & $2 / 46$ & 1.370 & .265 & 1.403 & .257 \\
\hline Job Hours & $17 / 47$ & 0.946 & .535 & 0.913 & .567 \\
\hline Job Type & $4 / 47$ & .577 & .681 & .270 & .896 \\
\hline Credit Load & $6 / 47$ & 1.210 & .321 & 1.037 & .416 \\
\hline Write & $2 / 46$ & 1.011 & .372 & 1.330 & .275 \\
\hline Math & $2 / 46$ & 1.427 & .251 & 2.746 & $.075^{*}$ \\
\hline Read & $6 / 47$ & 1.210 & .321 & 1.037 & .416 \\
\hline Listen & $2 / 46$ & 1.599 & .214 & .776 & .466 \\
\hline $\begin{array}{l}\text { FIN 320 } \\
\text { Grade }\end{array}$ & $8 / 47$ & 6.131 & $.000^{* * *}$ & 7.059 & $.000^{* * *}$ \\
\hline OGPA & $37 / 47$ & 6.583 & $.002^{* * *}$ & 7.997 & $.001^{* * *}$ \\
\hline Gender & $1 / 47$ & 1.770 & .190 & 1.649 & .206 \\
\hline Age & $1 / 47$ & 2.221 & .143 & 3.783 & $.058^{*}$ \\
\hline
\end{tabular}

* Significant at $10 \%$ level of significance using two tails test

** Significant at 5\% level of significance using two tails test

*** Significant at $1 \%$ level of significance using two tails test 


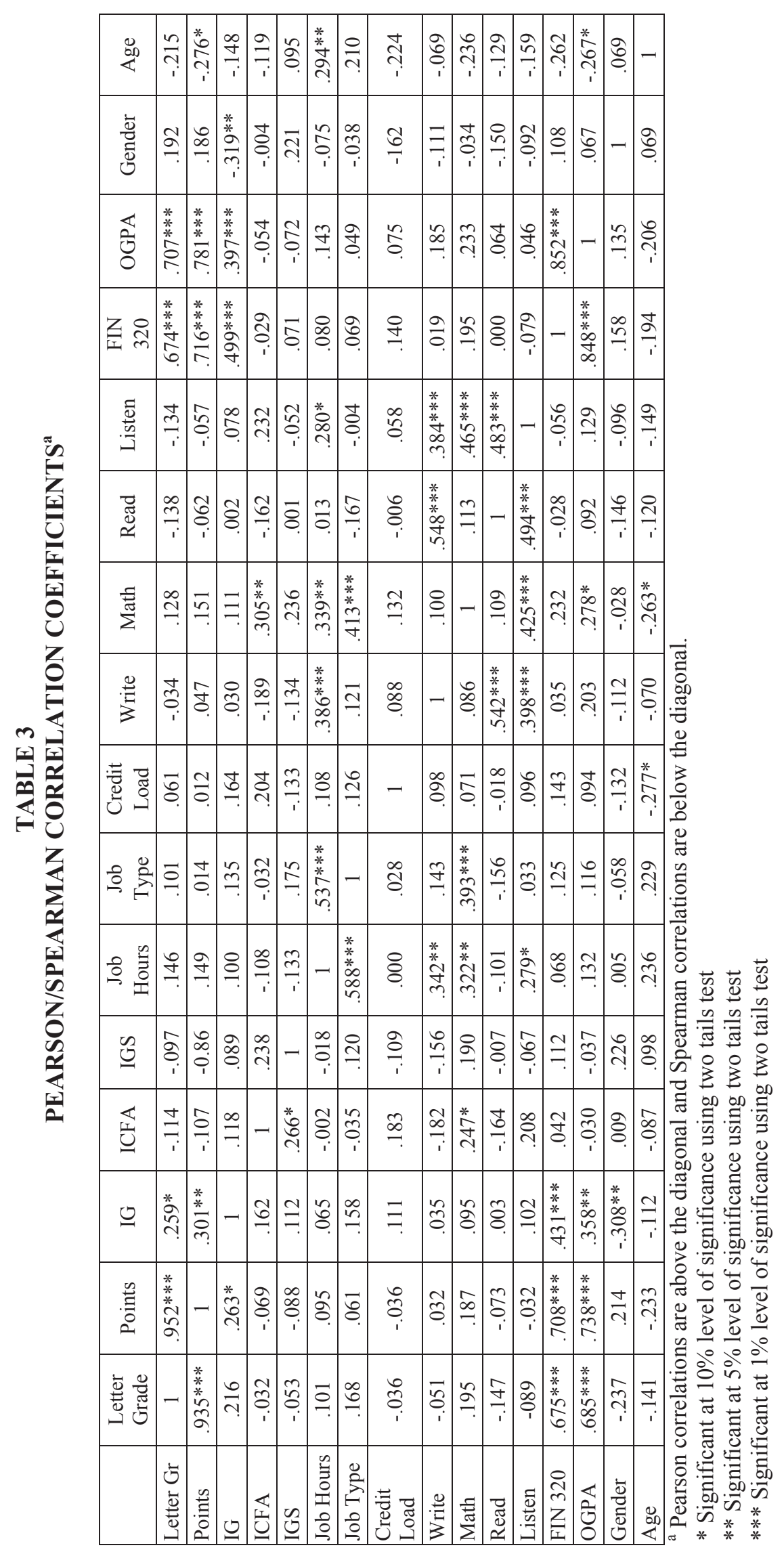

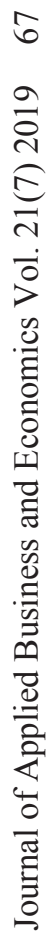




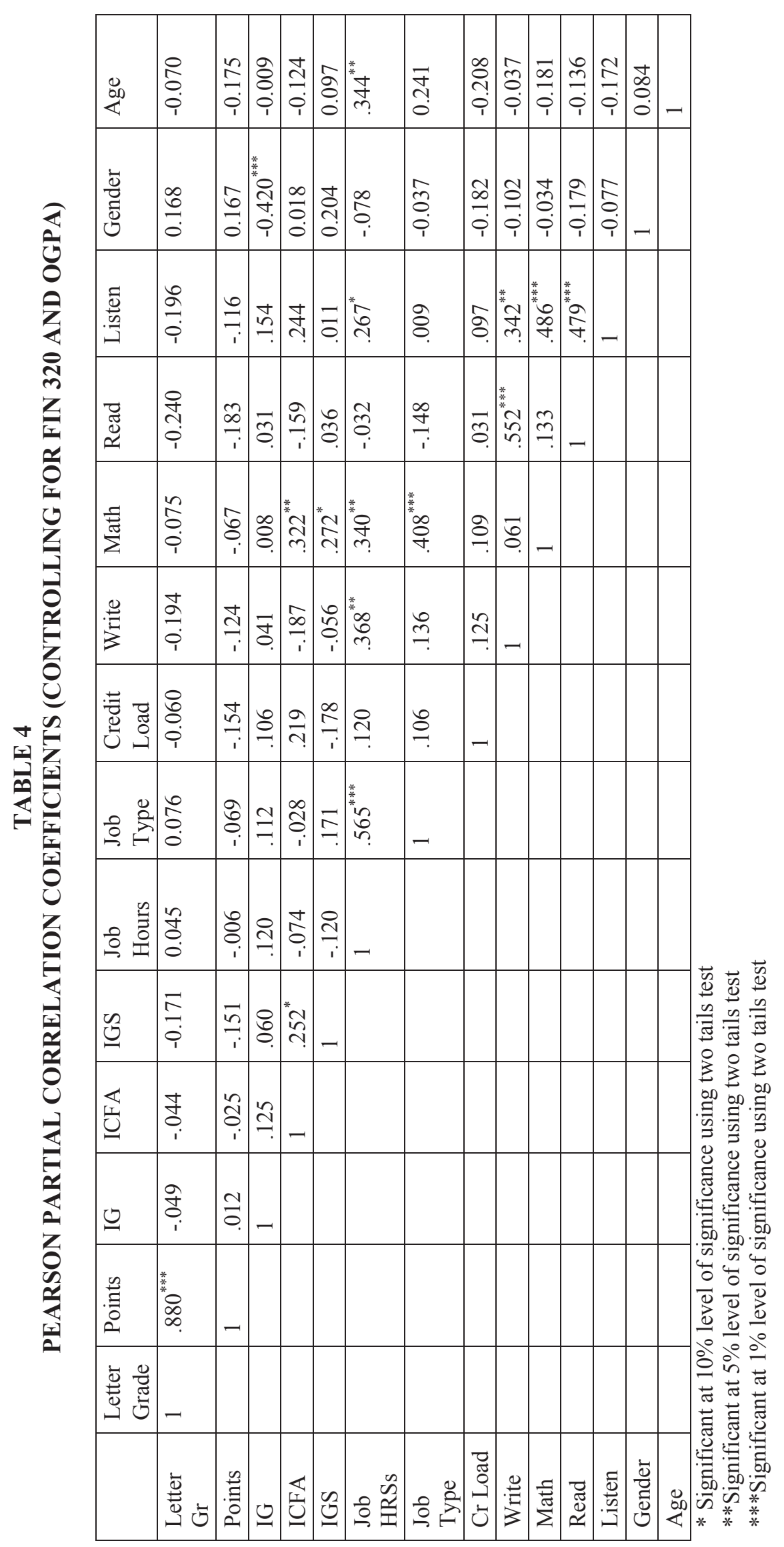

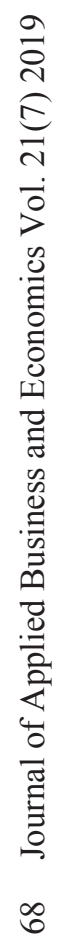


TABLE 5

REGRESSION ANALYSIS: ALL STUDY VARIABLE AND STUDENT PERFORMANCE

\begin{tabular}{|c|c|c|c|c|}
\hline \multirow{3}{*}{$\begin{array}{l}\text { Independent } \\
\text {. Variables }\end{array}$} & \multicolumn{4}{|c|}{ Dependent Variables } \\
\hline & \multicolumn{2}{|c|}{ Letter Grade } & \multicolumn{2}{|c|}{ Overall Points $\%$} \\
\hline & t Coeff. & Sig. & t Coeff. & Sig. \\
\hline Constant & .444 & .660 & 3.940 & $.000^{* * * *}$ \\
\hline $\mathrm{IG}$ & .337 & .738 & .803 & .428 \\
\hline ICFA & .227 & .822 & .271 & .788 \\
\hline IGS & -1.125 & .269 & -.963 & .343 \\
\hline Job Hours & .662 & .513 & .926 & .361 \\
\hline Job Type & .630 & .533 & -.243 & .809 \\
\hline Credit Load & -.596 & .555 & -1.274 & .212 \\
\hline Write & -.869 & .392 & -.425 & .673 \\
\hline Math & -.289 & .775 & -1.116 & .908 \\
\hline Read & .090 & .929 & -.100 & .921 \\
\hline Listen & -.738 & .466 & -.709 & .484 \\
\hline FIN 320 Gr. & .951 & .349 & .888 & .381 \\
\hline OGPA & 1.965 & $.058^{*}$ & 2.765 & $.010^{* * * *}$ \\
\hline Gender & 1.202 & .238 & 1.320 & .197 \\
\hline Age & -1.110 & .276 & -1.620 & .115 \\
\hline Adj. $R^{2}$ & .475 & & .625 & \\
\hline $\mathrm{F}$ & 3.906 & $0.001 * * *$ & 6.358 & $.000 * * *$ \\
\hline
\end{tabular}

* Significant at $10 \%$ level of significance using two tails test ** Significant at 5\% level of significance using two tails test

$* * *$ Significant at $1 \%$ level of significance using two tails test

TABLE 6

REGRESSION ANALYSIS: MOTIVATION FACTORS AND STUDENT PERFORMANCE

\begin{tabular}{|l|c|c|c|c|}
\hline \multirow{2}{*}{$\begin{array}{l}\text { Independent } \\
\text {.Variables }\end{array}$} & \multicolumn{4}{|c|}{ Dependent Variables } \\
\cline { 2 - 5 } & \multicolumn{2}{|c|}{ Letter Grade } & \multicolumn{2}{c|}{ Overall Points \% } \\
\cline { 2 - 5 } t Coeff. & Sig. & t Coeff. & Sig. \\
\hline Constant & 1.945 & $.058^{*}$ & 6.849 & $.000^{* * *}$ \\
\hline IG & 1.818 & $.076^{*}$ & 2.164 & $.036^{* *}$ \\
\hline ICFA & -.823 & .415 & -.831 & .410 \\
\hline IGS & -.607 & .547 & .573 & .569 \\
\hline Adj. R & .025 & & .050 & \\
\hline F & 1.387 & .260 & 1.809 & .160 \\
\hline
\end{tabular}

* Significant at $10 \%$ level of significance using two tails test

** Significant at $5 \%$ level of significance using two tails test

*** Significant at $1 \%$ level of significance using two tails test 
TABLE 7

REGRESSION ANALYSIS: DISTRACTION FACTORS AND STUDENT PERFORMANCE

\begin{tabular}{|c|c|c|c|c|}
\hline \multirow[b]{3}{*}{$\begin{array}{l}\text { Independen } \\
\text { t. Variables }\end{array}$} & \multicolumn{4}{|c|}{ Dependent Variables } \\
\hline & \multicolumn{2}{|c|}{ Letter Grade } & \multicolumn{2}{|c|}{ Overall Points \% } \\
\hline & $\begin{array}{c}\mathrm{t} \\
\text { Coeff. }\end{array}$ & Sig. & t Coeff. & Sig. \\
\hline Constant & 2.834 & $.007 * * *$ & 9.076 & $.000 * * *$ \\
\hline Job Hours & .717 & .477 & 1.123 & .267 \\
\hline Job Type & .153 & .879 & -.522 & .604 \\
\hline $\begin{array}{l}\text { Credit } \\
\text { Load }\end{array}$ & .291 & .772 & .015 & .988 \\
\hline Adj. $\mathrm{R}^{2}$ & -.043 & & -.038 & \\
\hline $\mathrm{F}$ & .358 & .783 & .425 & .736 \\
\hline
\end{tabular}

* Significant at $10 \%$ level of significance using two tails test

** Significant at $5 \%$ level of significance using two tails test

$* * *$ Significant at $1 \%$ level of significance using two tails test

TABLE 8

REGRESSION ANALYSIS: SELF-PERCEIVED ABILITY FACTORS AND STUDENT PERFORMANCE

\begin{tabular}{|c|c|c|c|c|}
\hline \multirow[b]{3}{*}{$\begin{array}{l}\text { Independent } \\
\text {. Variables }\end{array}$} & \multicolumn{4}{|c|}{ Dependent Variables } \\
\hline & \multicolumn{2}{|c|}{ Letter Grade } & \multicolumn{2}{|c|}{ Overall Points $\%$} \\
\hline & $\begin{array}{c}\mathrm{t} \\
\text { Coeff. }\end{array}$ & Sig. & t Coeff. & Sig. \\
\hline Constant & 3.442 & $.001 * * *$ & 8.985 & $.000 * * *$ \\
\hline Writing & .472 & .639 & .739 & .464 \\
\hline Math & 1.392 & .171 & 1.342 & .187 \\
\hline Reading & -.530 & .599 & -.391 & .698 \\
\hline Listening & -1.165 & .251 & -.910 & .368 \\
\hline Adj. $R^{2}$ & -.017 & & -.034 & \\
\hline $\mathrm{F}$ & .810 & .526 & .624 & .648 \\
\hline
\end{tabular}

* Significant at $10 \%$ level of significance using two tails test

** Significant at $5 \%$ level of significance using two tails test

*** Significant at $1 \%$ level of significance using two tails test 
TABLE 9

REGRESSION ANALYSIS: PRIOR ABILITY FACTORS AND STUDENT PERFORMANCE

\begin{tabular}{|c|c|c|c|c|}
\hline \multirow[b]{3}{*}{$\begin{array}{l}\text { Independent. } \\
\text { Variables }\end{array}$} & \multicolumn{4}{|c|}{ Dependent Variables } \\
\hline & \multicolumn{2}{|c|}{ Letter Grade } & \multicolumn{2}{|c|}{ Overall Points \% } \\
\hline & $\begin{array}{c}\mathrm{t} \\
\text { Coeff. }\end{array}$ & Sig. & t Coeff. & Sig. \\
\hline Constant & -1.473 & .148 & 4.781 & $.000 * * *$ \\
\hline FIN 320 & 1.320 & .194 & 1.040 & .304 \\
\hline OGPA & 2.446 & $.018 * *$ & 3.549 & $.001 * * *$ \\
\hline Adj. $\mathrm{R}^{2}$ & .497 & & .602 & \\
\hline $\mathrm{F}$ & 24.206 & $.000 * * *$ & 36.540 & $.000 * * *$ \\
\hline
\end{tabular}

* Significant at $10 \%$ level of significance using two tails test

** Significant at $5 \%$ level of significance using two tails test

$* * *$ Significant at $1 \%$ level of significance using two tails test

TABLE 10

REGRESSION ANALYSIS: OTHER FACTORS AND STUDENT PERFORMANCE

\begin{tabular}{|l|c|c|c|c|}
\hline \multirow{2}{*}{$\begin{array}{l}\text { Independent } \\
\text {. Variables }\end{array}$} & \multicolumn{4}{|c|}{ Dependent Variables } \\
\cline { 2 - 5 } & \multicolumn{2}{|c|}{ Letter Grade } & \multicolumn{2}{c|}{ Overall Points \% } \\
\cline { 2 - 5 } Coeff. & Sig. & t Coeff. & Sig. \\
\hline Gender & 5.472 & $.000 * * *$ & 15.262 & $.000^{* * *}$ \\
\hline Age & 1.460 & .151 & 1.468 & .149 \\
\hline Adj. $\mathrm{R}^{2}$ & -1.605 & .115 & -2.066 & $.045^{* *}$ \\
\hline F & .049 & & .079 & \\
\hline
\end{tabular}

* Significant at $10 \%$ level of significance using two tails test

** Significant at 5\% level of significance using two tails test

$* * *$ Significant at $1 \%$ level of significance using two tails test

TABLE 11

PARTIAL CORRELATION COEFFICIENTS OF SELECTED DISTRACTION FACTORS WITH STUDENT PERFORMANCE ${ }^{\mathrm{a}}$

\begin{tabular}{|l|c|c|c|c|l|c|c|c|c|}
\hline \multicolumn{4}{|c|}{ Panel A } & \multicolumn{4}{c|}{ Panel B } \\
\hline $\begin{array}{l}\text { Dependent } \\
\text { Variable }\end{array}$ & \multicolumn{2}{|c|}{ Letter Grade } & \multicolumn{2}{c|}{$\begin{array}{c}\text { Overall Points } \\
\%\end{array}$} & $\begin{array}{l}\text { Dependent } \\
\text { Variable }\end{array}$ & \multicolumn{2}{c|}{ Letter Grade } & \multicolumn{3}{c|}{$\begin{array}{c}\text { Overall Points } \\
\%\end{array}$} \\
\hline $\begin{array}{l}\text { Distraction } \\
\text { Factor }\end{array}$ & $\begin{array}{c}\mathrm{t} \\
\text { Coeff. }\end{array}$ & Sig. & $\begin{array}{c}\mathrm{t} \\
\text { Coeff. }\end{array}$ & Sig. & $\begin{array}{l}\text { Distraction } \\
\text { Factor }\end{array}$ & $\begin{array}{c}\mathrm{t} \\
\text { Coeff. }\end{array}$ & Sig. & $\begin{array}{c}\mathrm{t} \\
\text { Coeff. }\end{array}$ & Sig. \\
\hline JHours & .107 & .477 & .167 & .267 & JHours & -.044 & .777 & .124 &. .422 \\
\hline JType & .023 & .879 & -.078 & .604 & JType & .051 & .744 & -.097 & .531 \\
\hline Cr Load & .044 & .772 & .002 & .988 & Cr Load & -.031 & .844 & -.102 & .508 \\
\hline
\end{tabular}

a Panel A: While controlling for the other two distraction factors.

Panel B: While controlling for the other two distraction factors and prior actual ability factors (FIN 320 \& OGPA) 
TABLE 12

GRADE $\times$ AGE CROSS TABULATION COUNT

\begin{tabular}{|c|c|c|c|}
\hline \multirow{2}{*}{ Grade } & \multicolumn{3}{|c|}{ Age } \\
\cline { 2 - 4 } & $18-22$ & $23-27$ & Total \\
\hline F & 0 & 1 & 1 \\
\hline D- & 1 & 0 & 1 \\
\hline D & 1 & 0 & 1 \\
\hline D+ & 0 & 1 & 1 \\
\hline C & 4 & 2 & 6 \\
\hline C + & 2 & 0 & 2 \\
\hline B- & 1 & 0 & 1 \\
\hline B & 13 & 2 & 15 \\
\hline B + & 2 & 0 & 2 \\
\hline A- & 3 & 0 & 3 \\
\hline A & 12 & 3 & 15 \\
\hline Total & 39 & 9 & 48 \\
\hline
\end{tabular}

72 Journal of Applied Business and Economics Vol. 21(7) 2019 